\section{Frauke Hogue is an Expert in Metallurgy}

The inner structures of metals have fascinated Frauke Hogue, 77, since she was a young woman in Germany. Her Pacific Palisades home is decorated with enlarged pictures of the intricate patterns within pewter, titanium and other metals. She has created cards, pillows and even a shawl from the photos she takes by specially preparing the metals and using a light microscope that illuminate the varied colors and patterns within metals.

Few people know "how beautiful metals can be if you look at them the right way," said Hogue, who moved to Pacific Palisades with her husband in 1974. "Most people have never seen these types of views. It's not something that is common knowledge-except in the metallurgy field."

Within that field, Hogue's artwork has graced covers of metallurgy magazines, while her scientific findings have been presented in papers and at conferences. Recently, she has developed an interest in meteorites, which have far different patterns than human-made metals because of their uniquely slow cooling process-approximately one degree per million years.

The scientific aspect of the field initially attracted Hogue. As a child, she recalled an affinity for both math and physics, but, at the time, only the most brilliant women entered universities to study math and physics. She didn't consider herself in that category. When a female metallographer told her about a training program in Berlin that would allow her to learn metallography, Hogue enrolled.

The school, Lette Verein, founded in 1866, trained "women in jobs so that they could provide for themselves and did not have to rely on getting married," Hogue said. The technical field "required a lot of manual dexterity, and I really enjoyed the combination of science and hands-on" training. While most metallographers in Germany were women, Hogue found upon moving to the United States in 1967 that most metallographers here were male. It's no longer a male-only field in the U.S. According to the U.S. Department of Education, in 2017 women accounted for almost 3 in 10 graduates in material science, an umbrella major that includes the study of metals, plastics, composites, ceramics and other substances. Hogue's work, which she continues to do as a consultant and teacher, includes preparing metal samples through cutting, mounting, grinding and polishing them. Next, she etches them with specific chemicals that reveal the microstructure, which she examines at 100-1000 magnification with a light microscope, allowing her to see the materi-

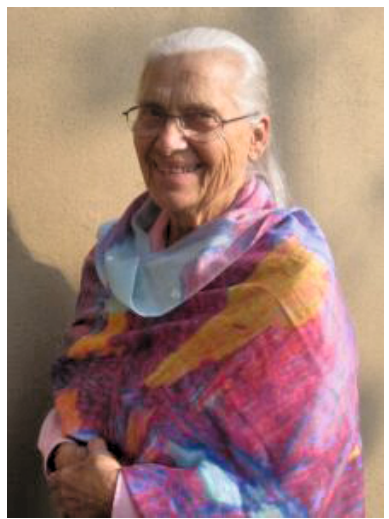

Frauke Hogue is wearing a shawl made from one of her titanium microstructures.

al type, strength, manufacturing technique and sometimes mode of failure.

She and other metallographers might analyze a piece of metal after an accident to uncover whether it was cooled at the wrong temperature or for too short a time. In addition, they might notice varied defects, such as cracks, corrosion and brittleness.

"From the patterns I see in there, I can see what the material is, how it failed, and all kinds of information," she said. These skills took many years to develop. "When you come out of college, you don't know anything yet. You have to learn how to look at things and what you have to look for. It's all experience."

Each summer, Hogue shares that experience with high school students at a free oneweek Materials Camp in Cleveland at ASM International, formerly known as the American Society for Metals. As part of 


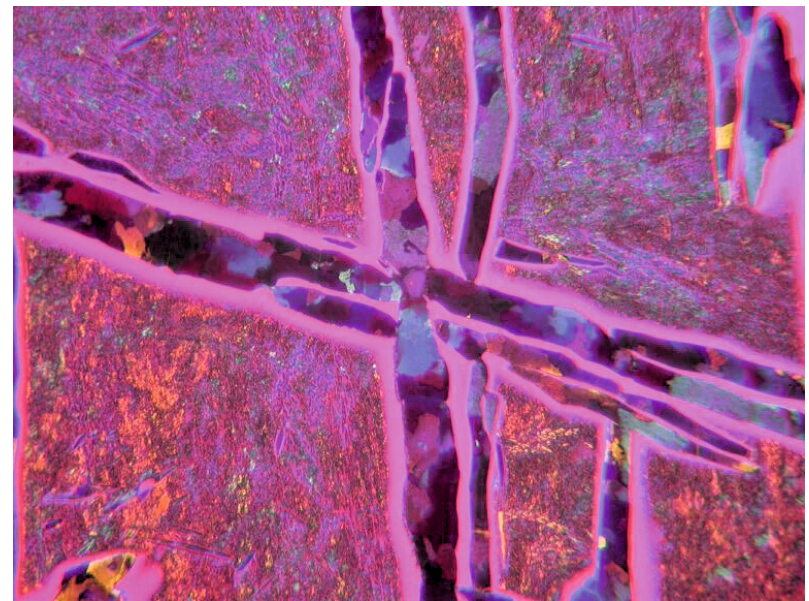

This is from a meteorite that landed in Africa.

the camp, the students solve the mystery of metal failure using a lab packed with the varied tools of material science.

"Being involved with the kids and always learning something keeps me young," she said, although last summer the pandemic meant the inperson camp was canceled. "I missed the connection" with the students, she noted, but a virtual version camp led to a virtual club, allowing the students to meet with her monthly to learn more.

In normal times, she also has developed and taught cours- es about microstructures at varied locations, ranging from conferences and institutions to companies that manufacture aircraft fasteners, which is where her career began.

In 1967, her first local job involved inspecting aircraft fasteners at Voi-Shan in Culver City, which employed several hundred people to make the products. Hogue did quality control to ensure proper manufacturing and processing were used, and she became the second salaried female employee of the company. After a decade, she transitioned to consultant work, in- cluding spates at SEAL Laboratories (Scanning Electron Analysis Laboratory), to create a schedule that adjusted better to her life as a new parent. She and her husband, Harlan, an architect, raised two sons, Henning, now 45, and Tauno, 42.

Throughout her adult life, her lively interest in the microstructure of metals and other substances has been a constant, in part because materials and their manufacture continually evolve. For example, 3D printing didn't exist when she began, and she describes the patterns the process creates as "un-uniform," as opposed to cast metals, which create dendritic patterns similar to a Christmas tree. Meteorites have also taken an increasing portion of her time as she purchases samples on Ebay to examine, and then creates art from them, while simultaneously gathering scientific data.

"I'm not done learning," said Hogue, who has a second home in Yucca Valley. "There's always something new, something different.... You always have to learn. That's very important in life."

Quelle: www.circlingthenews.com
We draw your attention to the fact that the individual pieces of information from the different sources will not be checked for accuracy. It is only possible to check for plausibility.
Wir weisen Sie darauf hin, dass die Nachrichten nicht auf ihre sachliche Richtigkeit, sondern nur auf Plausibilität überprüft werden.

\section{Bibliography}

DOI 10.1515/pm-2021-0028

Pract. Metallogr. 58 (2021) 6; page 377-378
(C) 2021 Walter de Gruyter $\mathrm{GmbH}$,

Berlin/Boston, Germany

ISSN 0032-678X · e-ISSN 2195-8599 